\title{
Arbuscular Mycorrhizal Fungi Limit Incidence of Fusarium oxysporum f.sp. albedinis on Date Palm Seedlings by Increasing Nutrient Contents, Total Phenols and Peroxidase Activities
}

\author{
Abohatem M., Chakrafi F., Jaiti F., Dihazi A. and M. Baaziz \\ Laboratoire des Biotechnologies, Valorisation et Protection des Plantes, Université Cadi Ayyad, Faculté des Sciences \\ Semlalia, B.P. 2390, 40000 Marrakech, Morocco
}

\begin{abstract}
Date palm seedlings derived from Jihel (JHL), a susceptible cultivar to Bayoud disease (fusariosis caused by Fusarium oxysporum f.sp. albedinis, Foa), were subjected to root inoculation with an arbuscular mycorrhizal fungus (AMF) collected from south Morocco and multiplied on barley as host plant. Successfully colonized plants by mycorrhizal fungi ( $85 \%$ of treated plants) produced typical intraradical structures (arbuscules, vesicles, hyphae). After ten months of colonization, mycorrhizal plants showed a significant increase in their growth expressed as shoot height, number of leaves per plant, shoot weight, root weight and the total biomass. Mycorrhizal and non-mycorrhizal (controls) date palm seedlings showed great differences in their leaf contents of phosphorus $(\mathrm{P})$, potassium $\left(\mathrm{K}^{+}\right)$and sodium $\left(\mathrm{Na}^{+}\right)$. When compared with controls, $\mathrm{P}$ increased more than two folds in mycorrhizal plants, while the values of $\mathrm{K}^{+}$and $\mathrm{Na}^{+}$ doubled. When inoculated with Foa by injecting roots with a spore suspension, mycorrhizal $(\mathrm{M}+$ Foa) and nonmycorrhizal $(\mathrm{C}+$ Foa) date palm seedlings showed significant increases in their root total phenols and peroxidase activities during the first month after inoculation. The highest increases were found in mycorrhizal seedlings accompanied by limited plant death. Mycorrhization alone did not affect significantly total phenols and peroxidase activities during the first week of culture. Plant death decrease in plant lots subjected to root inoculation with the he AMF fungus. As revealed by mycorrhization of date palm seedlings, these results supported the hypothesis that induced resistance to Bayoud disease is mediated by high increases in phenolic compounds and peroxidase activities. These results highlight the importance of mycorrhizal fungi as biocontrol agents to combat Bayoud disease and improve date palm culture in infected palm groves.
\end{abstract}

Keywords: Arbuscular mycorrhizal fungi, Date palm, Fusarium oxysporum f. sp. albedinis, Bayoud, growth, mineral nutrition, phenolic compounds, peroxidase.

\section{INTRODUCTION}

The ubiquitous arbuscular mycorrhizal fungi (AMF) are an integral component of any soil system where they form obligate symbiosis with the roots of over $80 \%$ terrestrial plant species [1].

This symbiosis is based on the beneficial exchange of reduced carbon from the plant and mineral nutrients, especially phosphate and nitrogen as well as water from the fungus $[2,3]$. AMF are of particular interest because of their positive effects on plant growth, health and protection against biotic and abiotic stresses [4]. This role of symbiotic associations has been studied in the case of several host plants such as clover [5], Ocimum basilicum L. [6], sesame [7], cucumber [8], tomato (Solanum lycopersicum L.) [9] and also in the date palm [10-13]. For date palm, Bouamra et al. [11] and Apple [14] have reported the role of mycorrhizal symbiosis in improving the uptake of phosphorus, nitrogen and trace elements. Shabbir et al. [15] showed that the inoculation of One-year-old in vitro seedlings of the date palm variety 'Khenizi' with a commercial AM inoculum, stimulated growth of date palm under salinity conditions.

*Address correspondence to this author at the Laboratoire des Biotechnologies, Valorisation et Protection des Plantes, Université Cadi Ayyad, Faculté des Sciences Semlalia, B.P. 2390, 40000 Marrakech, Morocco; Tel: 2125 24434649/ 2126 61368196; Fax: 2125 24437412; E-mails: baaziz@ucam.ac.ma,m_baaziz@hotmail.com
In the case of plant resistance against biotic stresses, AMF were found to be effective in reducing diseases caused by many pathogens such as Cylindrocladium, Fusarium, Macrophomina, Phytophthora, Pythium, Rhizoctonia, Sclerotinium and Verticillium [16].

In date palm (Phoenix dactylifera L.), Fusarium oxysporum f. sp. albedinis (Foa) causes a wilt disease called 'Bayoud'. It is a vascular pathogen that causes drastic reduction in cultivation and expansion of date palm in North Africa, leading to a considerable socio-economical impact. The control of Foa is difficult because chemical treatments are not effective and the prophylactic methods are not of interest due to the contamination of several palm plantations and to their non-durable impact. Therefore, planting resistant cultivars constitutes the only efficient and economic method to control Bayoud disease [17]. Oihabi [18] showed that the inoculation of date palm seedlings with Glomus mosseae reduced the Bayoud disease severity. Jaiti et al. [12] have also demonstrated the effectiveness of Glomus monosporus, Glomus deserticola and Glomus clarum in improvement of plant growth and reduction of Bayoud disease incidence. However, more data are needed about biochemical and physiological aspects of this interaction in date palm.

Mechanisms by which AMF improve resistance to biotic stresses are multiple and may include competition for infection site and host photosynthates, root damage compensa- 
tion, morphological changes in the host root, changes in microbial communities in the mycorrhizosphere and modifycations in the phytohormone balance in the roots of the host plants, with respect to cytokinins, gibberellins, ethylene, abscisic acid (ABA) and jasmonates [19, 20]. Biochemical and physiological modifications may occur, following mycorrhizal colonization. These changes covered the production of phenolic compounds [21, 22], lignin formation [23] and induction of new isoforms of the hydrolytic enzymes, such as chitinase and glucanase [24].

Peroxidases (EC 1.11.1.7) are very active oxidorectases studied in date palm considering their relationships with cultivar resistance to Bayoud disease [25, 26]. It has been reported previously that certain peroxidase fractions can modulate plant growth, in particular by their IAA oxidase activity [27, 28], while, other enzyme fractions could limit growth by tissue lignification and cell wall rigidification [29, 30]. Peroxidases were found to be involved in plant defenses against many pathogens. For example, reduction of the incidence of the banana Fusarium wilt was positively correlated with the induction of defense-related enzymes peroxidase and polyphenoloxidase [31]. As natural substrates of peroxidases and polyphenoloxidases, phenolic compounds and their oxidation products can play a major role in Ginseng resistance to root infecting Fusarium species [32]. Several reports reveal that typical plant defense responses against pathogenic microorganisms are also induced upon parasitic plant infection. These include an increase of peroxidase activity, lignification, and cell-wall phenolic deposition [33, 34].

Actually, more information is needed to understand the mechanisms by which AMF act as protectors of date palm against Bayoud disease. In a previous study, our team found that AMF stimulated growth of date palm seedlings derived from BFG cultivar [12] and induce plant protection against Foa by increasing peroxidase and polyphenoloxidase activities. Using another date palm cultivar (JHL), our present work plans to investigate the effect of AMF on plant nutrition and elucidate more details about the peroxidase-mediated protection of date palm against Bayoud disease, in term of root phenolic contents induced by the couple AMF-Foa.

The objective of this work is to study the beneficial role of complex of native AMF coming from the Aoufous date palm grove in the south of Morocco on the improvement of the growth and uptake of nutrient elements and to determine the potential induction by mycorrhization of some biochemical defense reactions that were previously shown to be involved in the mechanism of date palm resistance against Fusarium oxysporum f. sp. albedinis, causal agent of Bayoud disease, especially defense-related enzymes peroxidases and phenolic compounds [26, 35-38] .

\section{MATERIALS AND METHODS}

\subsection{Plant Material and Culture Conditions}

Seedlings of cultivar Jihel (JHL) date palm were obtained from seeds disinfected and cultivated in plastic containers filled with a mixture of sterile sand and peat. Then the seeds were incubated for three weeks at $38{ }^{\circ} \mathrm{C}$, before being transplanted into plastic bags containing sterile soil in a greenhouse under a $16 \mathrm{~h}$ light regime at $25^{\circ} \mathrm{C}$. The soil sterilized by autoclaving $\left(90{ }^{\circ} \mathrm{C}\right.$ for $\left.12 \mathrm{~h}\right)$ to eliminate native microflora and tested for its chemical and physical characteristics as follows: $\mathrm{pH} 8.7$, humidity $11.03 \%$, conductivity $477.67 \mu \mathrm{s} / \mathrm{cm}$, total nitrogen $0.0001 \%$, total carbon $0.61 \%$, available phosphor $0.00145 \%$ and exchangeable potassium $0.072 \%$.

\subsection{Biological Material, Growth Conditions and Mycorrhization of Date Palm Plants}

The mycorrhizal inoculum consists of Aoufous complex (CAF) which was isolated from soil of palm Tafilalet in the south of Morocco [39]. CAF contains a mixture of native arbuscular mycorrhizal fungi: Glomus sp. (15 spores/g soil), Sclerocystis sp. (9 spores/g soil) and Acaulospora sp. and Scutellospora $\mathrm{sp}$. (1 spore/g soil).

Barley was used as host plant for the multiplication of the mycorrhizal inoculums. Barley seeds were disinfected and germinated in plastic pots filled with soil containing mycorrhizal inoculums. After 3 months of culture mycorrhizal, the frequency of the mycorrhization of barley roots were estimated according to Phillips and Hayman [40]. The roots colonized by AMF were used as fresh mycorrhizal inoculums.

Mycorrhizal roots of barley are disinfected with a Strullu solution [41], containing streptomycin and chloramines $\mathrm{T}$ to eliminate other microorganisms than mycorrhizal fungi. They are then rinsed 3 times with distilled water and cut into fragments (1-2 $\mathrm{mm}$ in length). Then, those fragments (3 $\mathrm{g}$ per plant) were applied against the root of date palm plants to inoculate. The control date palm plants were cultivated without barley root fragments in the same conditions. Mycorrhizal plants and Control plants are grown in plastic bags with a diameter of $12 \mathrm{~cm}$ containing a soil and incubated under greenhouse conditions. Date palm plants were incubated in greenhouse under a $16 \mathrm{~h}$ light regime and $60-70 \% \mathrm{RH}$ at $25{ }^{\circ} \mathrm{C}$ and were irrigated weekly with $30 \mathrm{ml}$ of Long Ashton-modified Nutrient Solution [42].

\subsection{Estimation of AMF Colonization}

After 10 months of growth in the greenhouse, the roots of date palm were removed from the soil. Samples of plants were tested for determination of root colonization by AMF. These roots are treated according to the technique of Phillips and Hayman [40]. They were initially placed in $10 \% \mathrm{KOH}$ for clearing and stained with $0.01 \%$ trypan blue prepared in a solution of lactoglycerol. Roots were cut into $1 \mathrm{~cm}$ segments and 150 randomly selected segments were examined under a microscope for the evaluation of frequency $(\% \mathrm{~F})$ of AMF colonization as described by Trouvelot et al. [43].

\subsection{Growth Parameters}

The plant growth was estimated by calculating the height and the biomass production of shoots and the number of leaves formed per plant. The shoot and root weights of the fresh matter (FW) were measured before drying the material at $105{ }^{\circ} \mathrm{C}$ for 24 hours that leads to the weights of the dry matter (DW) for shoot and root. 


\subsection{Mineral Analysis}

Samples for analysis (leaf pieces of mycorrhizal and control seedlings from JHL date palm cultivar) were grounded with porcelain crucibles $(1 \mathrm{~g} /$ crucibles $)$ and ashed at $450{ }^{\circ} \mathrm{C}$ for 4 hours in a mineralizer such as MS Labover Montpellier France followed by dissolution in $20 \mathrm{ml}$ of $5 \mathrm{~N}$ hydrochloric acid and evaporated on a hot plate at low temperature. After evaporation, $2 \mathrm{ml}$ of distilled water and $2 \mathrm{ml}$ of $5 \mathrm{~N} \mathrm{HCl}$ were added. The solution was filtered through filter paper and the filtrate volume was adjusted to $50 \mathrm{ml}$ with distilled water. The phosphorus content is measured by the spectrophotometer assay and the levels of sodium and potassium were determined by flame emission spectrophotometry using Flame photometer.

\subsection{Effect of AMF Colonization on Induction of Biochemical Defense Reactions}

After ten months of colonization of plant date palm by CAF, 30 plants ( 15 colonized and 15 non-mycorrhizal) were inoculated with the pathogen Foa and 30 others were kept as uninoculated healthy controls. The strain used is ZAG Foa; aggressive strain isolated from palm spine taken from infected foot with the palm of Bayoud in Draa [44]. Inoculation with Foa was performed by injecting $20 \mu \mathrm{l}$ of a conidial suspension $(107$ spores $/ \mathrm{ml})$ into the main root of each plant. Control plants were maintained under the same conditions but injected with distilled water.

\subsection{Analyses of Biochemical Parameters}

The kinetics changes of enzyme activities and levels of soluble phenols in root samples were took from inoculated plants and control plants at $0,1,7,15$ days and 1 month after inoculation with Foa.

\subsubsection{Analysis of Soluble Phenols}

Phenolic compounds were extracted and analysed as described by El Hadrami et al. [35]. $500 \mathrm{mg}$ of fresh roots were homogenized in $2 \mathrm{ml}$ methanol $(80 \%)$ at $4{ }^{\circ} \mathrm{C}$ and centrifuged 15 minutes at 9000 g. $50 \mu \mathrm{l}$ of the phenolic extract were added to $250 \mu \mathrm{l}$ of Folin-Ciocalteu reagent and $500 \mu \mathrm{l}$ of a solution of calcium carbonate $20 \%$. The mixture was incubated in a water bath at $40{ }^{\circ} \mathrm{C}$ for 30 minutes and determined by spectrophotometry at $760 \mathrm{~nm}$. The levels of phenolics were expressed as mg equivalent of catechin per $g$ of FW. Three replicates were realized for each assay

\subsubsection{Analysis of Peroxidases}

Fresh roots $(200 \mathrm{mg})$ were homogenized in $1 \mathrm{ml}$ of Tris maleate buffer $(0.1 \mathrm{M}, \mathrm{pH}$ 6.5) containing Triton X-100 (0.1 $\mathrm{g} / \mathrm{l}$ ) and centrifuged for 15 minutes at $9000 \mathrm{~g}$. Peroxidase activity was assayed spectrophotometry at $470 \mathrm{~nm}$ using guaiacol as substrate; $20 \mu \mathrm{l}$ of the enzyme extract were added to $2 \mathrm{ml}$ of reaction mixture (Tris-maleate $0.1 \mathrm{M}, \mathrm{pH}$ $6.5+25 \mathrm{mM}$ Guaiacol). Reaction were initiated with $20 \mu \mathrm{l}$ of $\mathrm{H}_{2} \mathrm{O}_{2}(10 \%)$ and followed for 3 minutes [12]. Three replicates were realized for each assay.

\subsection{Statistical Analysis}

The data were statistically analyzed by ANOVA with STATISTICA version 6 [45]. Duncan test [46] was used for mean comparison. Statistical differences mentioned in the text are significant at $\mathrm{p}=0.05$.

\section{RESULTS}

\subsection{Frequency of Mycorrhization. Microscope Observa- tions}

As checked by microscope observations, all mycorrhizal plants were successfully colonized by AM fungi complex Aoufous and produced typical intraradical structures (arbuscules (A), vesicles (V), hyphae (H)) as shown in Fig. (1).

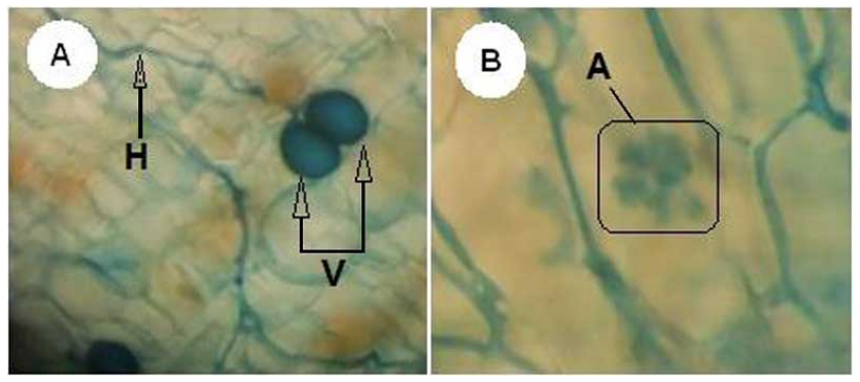

Fig. (1). Observations by light microscopy of date palm seedling roots colonized by AMF (GX 40). A: vesicle (V) and hyphae (H) structures; B: arbuscule.structure (A).

The frequency of mycorrhization of all treated plants reached $85 \%$ and the control plants (non-inoculated) are actually non-mycorrhizal.

\subsection{Growth Parameters}

After 10 months of mycorrhization, mycorrhizal plants significantly increased shoot height and number of leaves per plant as compared to the control plants (Table 1).

Table 1. Measurements of Shoot Height, Shoot Weight, Root Weight, Total Biomass and Number of Leaves in Date Palm Seedlings from JHL Cultivar Colonized by AMF (Mycorrhized Plants) and NonMycorrhized Seedlings (Control Plants) after 10 Months of Mycorrhization with CAF (Aoufous Complex). Shoot Weight and Root Weight are Expressed on the Basis of Fresh Matter (FW) and Dry Matter (DW)

\begin{tabular}{|c|c|c|c|}
\hline \multicolumn{2}{|l|}{ Treatments } & Control Plants & Mycorrhized Plants \\
\hline \multicolumn{2}{|c|}{ Shoot height $(\mathrm{cm})$} & $37.16 \pm 0.49 \mathbf{a}$ & $44.12 \pm 0.56 \mathbf{b}$ \\
\hline \multirow{2}{*}{$\begin{array}{c}\text { Shoot weight } \\
\text { (g) }\end{array}$} & $\mathrm{FW}$ & $20.91 \pm 2.4 \mathbf{a}$ & $30.06 \pm 3.2 \mathbf{b}$ \\
\hline & DW & $7.03 \pm 0.4 \mathbf{a}$ & $11.12 \pm 0.5 \mathbf{b}$ \\
\hline \multirow{2}{*}{$\begin{array}{l}\text { Root weight } \\
\text { (g) }\end{array}$} & FW & $12.04 \pm 1.2 \mathbf{a}$ & $15.39 \pm 1.6 \mathbf{b}$ \\
\hline & DW & $3.26 \pm 0.2 \mathbf{a}$ & $4.04 \pm 0.3 \mathbf{b}$ \\
\hline \multirow{2}{*}{ Total biomass (g) } & FW & $32.95 \pm 3.6 \mathbf{a}$ & $45.45 \pm 4.8 \mathbf{b}$ \\
\hline & DW & $10.29 \pm 0.6 \mathbf{a}$ & $15.16 \pm 0.8 \mathbf{b}$ \\
\hline \multicolumn{2}{|c|}{$\begin{array}{c}\text { Number of leaves } \\
\text { per plant }\end{array}$} & $5.88 \pm 0.10 \mathbf{a}$ & $6.36 \pm 0.08 \mathbf{b}$ \\
\hline
\end{tabular}

Values are means \pm standard error of three replicates from two experiments. For each growth parameters, values followed different letters $(a-b)$ are significantly different at $\mathrm{p}=0.05$ level. 
In addition, mycorrhizal plants showed a significant increase in weights of the fresh matter (FW) and dry matter (DW) of shoots (30.06 and $11.12 \mathrm{~g}$ ) compared with the control plants (20.91 and $7.03 \mathrm{~g}$ ). A same trend was obtained for roots. Concerning the total fresh and dry biomass, mycorrhizal plants had values (45.45 and $15.16 \mathrm{~g})$ significantly higher when compared with controls (32.95 and $10.29 \mathrm{~g}$ ) (Table 1).

\subsection{Mineral Analysis}

Analysis of leaf mineral compositions showed a significant increase in phosphorus $(\mathrm{P})$, potassium $\left(\mathrm{K}^{+}\right)$and sodium ion $\left(\mathrm{Na}^{+}\right)$in mycorrhizal plants when compared with control plants (Table 2). The highest increase was obtained for the phosphorus mineral, where mycorrhizal plants showed more than twofold the phosphorus content of control plants.

Table 2. Determination of Total Phosphorus, Potassium and Sodium in Date Palm Seedlings of JHL Cultivar Colonized by AMF and Control

\begin{tabular}{|c|c|c|c|}
\hline Treatment & {$[\mathbf{P}]$} & {$[\mathbf{K}+]$} & {$[\mathbf{N a}+]$} \\
\hline \hline Control JHL & $0.533 \pm 0.118 \mathbf{a}$ & $3.645 \pm 0.499 \mathbf{a}$ & $0.628 \pm 0.075 \mathbf{a}$ \\
\hline mycorrhizal JHL & $1.193 \pm 0.183 \mathbf{b}$ & $5.319 \pm 1.312 \mathbf{b}$ & $1.076 \pm 0.069 \mathbf{b}$ \\
\hline
\end{tabular}

Values are means \pm standard error of three replicates from two experiments. For each treatment, values followed by the same letters $(\mathrm{a}-\mathrm{b})$ are not significantly different at $\mathrm{p}$ $=0.05$ level.
3.4. Total Phenols and Peroxidase Activities. Effect of Inoculating Mycorrhizal and Non-Mycorrhizal Date Palm Seedling with Fusarium oxysporum f. sp. albedinis, the Causal Agent of Bayoud Disease

Results presented in Table $\mathbf{3}$ showed that mycorrhizal and not mycorrhizal date palm seedlings exhibited no substantial changes in their root contents of total phenols during the first month of culture. However, Fifteen days after Foa inoculation, seedling roots started to show significant increases in the amount of total phenols in mycorrhizal and non-mycorrhizal plants. In addition, this period was marked by the appearance of external symptoms typifying Bayoud disease (whitening and wilting leaves). This increase is more important in the mycorrhizal plants and was more pronounced 30 days after the pathogen infection where The Total phenol content reached $136.43 \mathrm{mg} / \mathrm{g} \mathrm{FW}$ in mycorrhizal plants and only $97.86 \mathrm{mg} / \mathrm{g} \mathrm{FW}$ in non mycorrhizal plants. Limited plant death observed in mycorrhizal seedlings, coincided with high root phenolic contents induced by Foa inoculation.

Regarding root peroxidase activities, the tendency of changes was found to be similar to root phenolic contents. Thus, peroxidase activities of date palm seedlings were not significantly affected by mycorrhization (Table 4). However, Foa infection significantly enhanced this activity in mycorrhizal plants $(\mathrm{M}+$ Foa) than non-mycorrhizal $(\mathrm{C}+$

Table. 3. Total Phenol Contents in Roots of Mycorrhizal Date Palm Seedlings from JHL Cultivar (M) and Control Plants (C), Compared with Total Phenols Obtained 0, 1, 7, 15 and 30 Days after Foa Inoculations of Mycorrhizal (M + Foa) and NonMycorrhizal (C + Foa) Plants, Showing Different Levels in Plant Death

\begin{tabular}{|c|c|c|c|c|c|}
\hline \multirow{2}{*}{ Treatment } & \multicolumn{5}{|c|}{ Total Phenol Content (mg/g FW) } \\
\cline { 2 - 6 } & $\mathbf{0 ~ d a y}$ & $\mathbf{1 ~ d a y}$ & $\mathbf{7 d a y}$ & $\mathbf{1 5}$ day & 30 day \\
\hline \hline C & $34.85 \pm 5.67 \mathbf{a}$ & $31.44 \pm 8.94 \mathbf{a}$ & $28.80 \pm 10.27 \mathbf{a}$ & $32.00 \pm 6.99 \mathbf{a}$ & $33.05 \pm 3.03 \mathbf{a}$ \\
\hline M & $32.27 \pm 8.32 \mathbf{a}$ & $36.65 \pm 8.99 \mathbf{a}$ & $25.64 \pm 5.78 \mathbf{a}$ & $41.47 \pm 21.04 \mathbf{a b}$ & $39.03 \pm 5.73 \mathbf{a}$ \\
\hline C+Foa & $41.76 \pm 4.93 \mathbf{a}$ & $42.01 \pm 14.63 \mathbf{a}$ & $44.18 \pm 6.07 \mathbf{a}$ & $58.85 \pm 11.94 \mathbf{b c}$ & $97.86 \pm 4.18 \mathbf{b}$ \\
\hline M+Foa & $43.41 \pm 11.55 \mathbf{a}$ & $48.65 \pm 7.33 \mathbf{a}$ & $54.60 \pm 11.59 \mathbf{a}$ & $106.35 \pm 7.91 \mathbf{c}$ & $136.43 \pm 11.51 \mathbf{c}$ \\
\hline Plant death (C+Foa) & $0 \%(-)$ & $0 \%(-)$ & $0 \%(-)$ & $4.6 \%(+)$ & $10.3 \%(++)$ \\
\hline Plant death (M+Foa) & $0 \%(-)$ & $0 \%(-)$ & $0 \%(-)$ & $3.2 \%(+)$ & $4.8 \%(+)$ \\
\hline
\end{tabular}

Values are means \pm standard error of three replicates from two experiments. For each treatment, values followed by the same letters $(\mathrm{a}-\mathrm{c})$ are not significantly different at $\mathrm{p}=0.05$ level.

Table. 4. Peroxidase Activities in Roots of Mycorrhizal Date Palm Seedlings from JHL Cultivar (M) and Control Plants (C), Compared with Peroxidase Activities Obtained 0, 1, 7, 15 and 30 Days after Foa Inoculations of Mycorrhizal (M + Foa) and Non-Mycorrhizal (C + Foa) Plants

\begin{tabular}{|c|c|c|c|c|c|}
\hline Treatment & \multicolumn{5}{|c|}{ Peroxidase Activity (U/g FW) } \\
\hline $\mathrm{C}$ & $161.05 \pm 10.22 \mathbf{a}$ & $239.89 \pm 61.63 \mathbf{a}$ & $384.84 \pm 130.01 \mathbf{a}$ & $372.53 \pm 24.31 \mathbf{a}$ & $297.10 \pm 43.35 \mathbf{a}$ \\
\hline $\mathrm{C}+\mathrm{Foa}$ & $210.76 \pm 66.25 \mathrm{a}$ & $321.42 \pm 52.88 \mathbf{a}$ & $332.00 \pm 96.85 \mathbf{a}$ & $522.67 \pm 64.49 \mathbf{a b}$ & $631.93 \pm 10.92 \mathbf{a b}$ \\
\hline M & $243.12 \pm 178.93$ a & $236.84 \pm 118.8 \mathbf{a}$ & $382.98 \pm 46.56 \mathbf{a}$ & $465.57 \pm 16.56$ bc & $443.37 \pm 140.27 \mathbf{b}$ \\
\hline
\end{tabular}

Values are means \pm standard error of three replicates from two experiments. For each treatment, values followed by the same letters $(\mathrm{a}-\mathrm{c})$ are not significantly different at $\mathrm{p}=0.05$ level.

Percentages of plant death are the same as presented in Table 3. 
Foa) ones. Thus, 15 days after Foa inoculation, mycorrhizal plants high peroxidase activity $(661.53 \mathrm{U} / \mathrm{g} \mathrm{FW})$ than nonmycorrhizal seedlings $(522.67 \mathrm{U} / \mathrm{g} \mathrm{FW})$. This difference becomes higher after 1 month of Foa inoculation, when enzymes activities reached 1031.95 and $631.93 \mathrm{U} / \mathrm{g}$ FW for mycorrhizal and non-mycorrhizal plants, respectively. As mentioned for total phenol variations (Table 3), limited plant death fits with high levels of peroxidase activities induced by Foa in mycorrhizal plants.

\section{DISCUSSION}

Considered as a contribution to protect date palm (Phoenix dactylifera L.) against Bayoud disease, this study highlights physiological and biochemical aspects of date palm AMF mycorrhization, which could enhance resistance through the improvement of growth (nutrient supply) and the activation of the defense mechanisms of host plants against of Fusarium oxysporum f. albedinis sp, the causal agent of Bayoud disease.

Ten months after installation of mycorrhization, microscope observations confirmed the success of plant colonization by AM fungi complex Aoufous. Typical intraradical structures (arbuscules (A), vesicles $(\mathrm{V})$, hyphae $(\mathrm{H})$ ) were observed as shown in figure 1. Date palm seedlings derived from JHL cultivar (susceptible variety to Bayoud disease), showed a high frequency of mycorrhization (85\%). This data is in accordance with previous results obtained by our team who reported a frequency of mycorrhization of the same AMF up to $83.33 \%$ obtained for BFG, another Bayoud-susceptible date palm cultivar [12]. These data reflect the ability of species forming the complex CAF to colonize the root system of date palm.

After ten months of colonization, mycorrhizal plants showed a significant increase in their growth expressed as shoot height, number of leaves per plant, shoot weight, root weight and the total biomass. This plant response to mycorrhization has been obtained for many other plant species, such as Cupressus atlantica [47] and Citrus tangerine [48]. The stimulated growth of Mycorrhizal date palm seedlings was accompanied by increases in their leaf contents of phosphorus $(\mathrm{P})$, potassium $\left(\mathrm{K}^{+}\right)$and sodium $\left(\mathrm{Na}^{+}\right)$. This positive effect of AMF on the various parameters of growth can be explained by improving the nutritional status of date palm, including mineral nutrition. This growth stimulation was also reported in other plants such as strawberry [49], licorice [50] and alfalfa [51]. It was attributed to increases in the capacity of host plants to explore a larger soil volume leading to more nutrient assimilation [52].

In the second part of this work, we reported for the first time that limited death of mycorrhizal seedlings derived from the date palm cultivar JHL and inoculated with Foa (the causal agent of Bayoud disease), was found to be associated with significant increases in root phenolic contents. Changes in phenolic contents have been reported before in other fusariosis, such as the tomato wilt [53], where Fusarium oxysporum strain CS-20, previously shown to reduce the incidence of Fusarium wilt of tomato (biocontrol) through an uncharacterized host-mediated response, acted by alterations in tomato secondary metabolism (phenolic compounds) that are typical of resistance responses against Fusarium oxysporum f. sp. lycopersici.

Studying the effects of mycorrhizal fungal inoculations of Glomus species on phenolic compounds and pathogenesis related proteins in pepper - Phytophthora capsici that plant pathosystem, Ozgonen et al. [54] found that total phenolic compounds increased in all treatments as compared to non mycorrized non pathogen treated control, but was highest when plants were inoculated with both, the mycorrhizal fungi and the pathogen.

The present work showed that changes in the activities of peroxidase extracted from roots of the date palm cultivar JHL followed a same trend as changes of phenolic contents. This finding complete data previously published by our team [12], where changes in phenolic contents have not been studied. However, qualitative aspects of induced phenolic compounds (hydroxycinnamic acid derivatives) have been reported in mycorrhized date palm seedlings challenged with Foa [38]. The increased level of phenolics could provide an adequate substrate to oxidative reactions catalysed by POD and/or PPO that, consuming oxygen and producing fungitoxic quinones, make the medium unfavourable to the further development of pathogens, as suggested by Lattanzio et al. (2006) [55]. In the infectious process, plant cells usually respond by increasing the level of pre-existing antifungal phenols at the infection site, after an elicited increased activity of the key enzymes (PAL and chalcone synthase) of the biosynthetic pathway $[55,56]$. It was demonstrated that Stems of resistant flax lines contained a higher content of total phenols than susceptible ones upon pathogen challenge. The activity of peroxidase, polyphenyl oxidase, catalase enzymes as well as proline content were significantly increased in powdery mildew infected leaves of flax lines as compared with either resistant or susceptible parents [57].

In conclusion, these results are indicative of the important role played by the AMF associated with date palm seedlings in their development and their resistance to Foa. The effectiveness of the CAF mycorrhizal association acted on two levels; i) Enhancing nutrient supply, in particular P and $\mathrm{K}$ elements that stimulate growth and, ii) Stimulation of defense mechanisms through increasing total phenols and peroxidases activities. This mycorrhizal association may be used as a promising strategy to develop tools to fight against Bayoud disease.

\section{ACKNOWLEDGEMENT}

M. Baaziz (here author) is a member of the editorial board of TOHORTJ. He is entitled for FREE publication of ONE ARTICLE each year.

\section{CONFLICTS OF INTEREST}

The manuscript submitted has been prepared according to the journal's 'Aims and Scope' and 'Instructions for Authors', and checked for all possible inconsistencies and typographical errors.

On submission of the manuscript, the authors agree not to withdraw their manuscript at any stage prior to publication. 


\section{REFERENCES}

[1] Van der Heijden MGA, Sanders IR. Mycorrhizal ecology. Ecological studies. New York, USA: Springer-Verlag 2002.

[2] Smith SE, Read DJ. Growth and carbon economy of VA mycorrhizal plants. In: Smith SE, Read DJ, Eds. Mycorrhizal symbiosis. Academic: London 1997; p. 105-25.

[3] Dreyer B, Morte A, Ángel Lopez J, Honrubia M. Comparative study of mycorrhizal susceptibility and anatomy of four palm species. Mycorrhiza 2010; 20: 103-15.

[4] Berta G, Sampo S, Gamalero E, Massa N, Lemanceau P. Suppression of Rhizoctonia root-rot of tomato by Glomus mosseae BEG12 and Pseudomonas fluorescens A6RI is associated with their effect on the pathogen growth and on the root morphogenesis. Eur J Plant Pathol 2005; 111: 279-88.

[5] Oihabi A, Meddich A. Effet des mycorhizes à arbuscules (MA) sur la croissance et la composition minérale du trèfle. Cahiers de l'agricultre 1996; 5: 382-6.

[6] Copetta A, Lingua G, Berta G. Effects of three AM fungi on growth, distribution of glandular hairs, and essential oil production in Ocimum basilicum L. var. Genovese. Mycorrhiza 2006; 16 (7): 485-94.

[7] Boureima S, Diouf M, Diop TA, et al. Effects of arbuscular mycorrhizal inoculation on the growth and the development of sesame (Sesamum indicum L.). Afr J Agric Res 2007; 3 (3): 234-8.

[8] Gamalero E, Berta G, Massa N, Glick BR, Linqua G. Synergistic interactions between the ACC deaminase producing bacterium Pseudomonas putida UW4 and the AM fungus Gigaspora rosea positively affect cucumber plant growth. FEMS Microbiol Ecol 2008; 64 (3): 459-67.

[9] Siddiqui ZA, Sayeed Akhtar M. Effects of antagonistic fungi, plant growth- promoting rhizobacteria, and arbuscular mycorrhizal fungi alone and in combination on the reproduction of Meloidogyne incognita and growth of tomato. J Gen Plant Pathol 2009; 75 (2): 144-53.

[10] Oihabi A, Perrin R, Marty F. Effect of VA mycorrhizae on growth and mineral nutrition of date palm. Revue du réseau pour l'amélioration de la productivité agricole en milieu aride. 1993; 5: $1-9$.

[11] Bouamra R, Dalpe Y, Serrhini MN, Bennani A. Arbuscular mycorrhizal fungi species associated with rhizosphere of Phoenix dactylifera L. in Morocco. Afr J Biotechnol 2006; 5 (6): 510-6.

[12] Jaiti F, Meddich A, El Hadrami I. Effectiveness of arbuscular mycorrhizal fungi in the protection of date palm (Phoenix dactylifera L.) against Bayoud disease. Physiol Mol Plant Pathol 2007; 71 (4-6): 166-73.

[13] Souna F, Chafi A, Chakroune K, Himri I, Bouakka M, Hakkou A. Effect of mycorhization and compost on the growth and the protection of date palm (Phoenix Dactylifera L.) against bayoud disease. American-Eurasian J Sustainab Agricul 2010; 4(2): 260-7.

[14] Apple ME. Aspects of mycorrhizae in desert plants. Desert Plants 2010; 1: 121-34.

[15] Shabbir G, Dakheel AJ, Al-Naqbi MRS. The effect of arbuscular mycorrhiza (AM) fungi on the establishment of date palm (Phoenix dactylifera L.) under saline conditions in the UAE. Acta Hortic (ISHS) 2010; 882: 303-14.

[16] Harrier LA, Watson CA. The potential role of arbuscular mycorrhizal (AM) fungi in the bioprotection of plants against soil borne pathogens in organic and/or other sustainable farming systems. Pest Manag Sci 2004; 60 (2): 149-57.

[17] Saaidi M. Comportement au champ de 32 cultivars de palmier dattier vis-à-vis du bayoud: 25 années d'observations. Agronomie 1992; 12: 359-70.

[18] Oihabi A. Etude de l'influence des mycorhizes à vésicules et arbuscules sur le Bayoud et la nutrition du palmier dattier. Doctorat d'Etat, Université Cadi Ayyad, Faculté des Sciences Semlalia-Marrakech, Maroc 1991; p.110.

[19] López-Ráez JA, Verhage A., Fernández I, et al. Hormonal and transcriptional profiles highlight common and differential host responses to arbuscular mycorrhizal fungi and the regulation of the oxylipin pathway. J Exp Bot 2010; 61: 2589-601.

[20] Martínez-Medina A, Roldá A, Albacete A, Pascual JA. The interaction with arbuscular mycorrhizal fungi or Trichoderma harzianum alters the shoot hormonal profile in melon plants. Phytochemistry 2011; 72: 223-9.

[21] Sylvia DM, Sinclair WA. Phenolic compounds and resistance to fungal pathogens induced in primary roots of Douglas-fir seedlings by the ectomycorrhizal fungus Laccaria laccata. Phytopathology 1983; 73: 390-7.

[22] Zeng RS. Disease resistance in plants through mycorrhizal fungi induced allelochemicals. In: Inderjit KG, Mukerji, Eds. Allelochemicals: biological control of plant pathogens and diseases. Dordrecht, The Netherlands: Springer 2006; pp. 181-92.

[23] Saldajeno MG, Chandanie WA, Kubota M, Hyakumachi M. Effects of interactions of arbuscular mycorrhizal fungi and beneficial saprophytic mycoflora on plant growth and disease protection. In: Siddiqui ZA, Akhtar MS, Futai K, Eds. Mycorrhizae: sustainable agriculture and forestry. The Netherlands: Springer 2008; p. 21126.

[24] El-Khallal SM. Induction and modulation of resistance in tomato plants against Fusarium wilt disease by bioagent fungi (arbuscular mycorrhiza) and/or hormonal elicitors (jasmonic acid and salicylic acid): 2-changes in the antioxidant enzymes, phenolic compounds and pathogen related-proteins. Aust J Basic Appl Sci 2007; 1(4): 717-32.

[25] Baaziz M, Saadi M. Preliminary identification of date palm cultivars by esterase isoenzymes and peroxidase activities. Can J Bot 1988; 66: 89-93.

[26] Baaziz M. The activity and preliminary characterization of peroxidases in leaves of cultivars of date palm, Phoenix dactylifera L. New Phytol 1989; 111: 403-11.

[27] Gaspar T, Kevers C, Hausman J F, Berthon JY, Ripetti V. Peroxidase activity and endogenous free auxin during adventitious root formation. In: P.J. Lumsden, J.R. Nicholas, W.J. Davies, Eds. Physiology, growth and development of plants in culture. Kluwer Academic, Dordrecht 1994; pp. 289-98.

[28] Fry SC. Cross-linking of matrix polymers in the growing cell walls of angiosperms. Ann Rev Plant Physiol 1986; 37: 165-8.

[29] Polle A, Otter T, Seifert F. Apoplastic peroxidase and lignification in needles of Norway spruce (Picea abies L.). Plant Physiol 1994; 106: 53-60.

[30] Aouad A, Baaziz M, Margoum M. Quantitative and qualitative aspects of peroxidases in some Moroccan cereal varieties and their relationships with the in vitro growth potential. Plant Peroxidase Newslett 2000; 15: 13-21.

[31] Akila R, Rajendran L, Harish S, Saveetha K, Raguchander T, Samiyappan R. Combined application of botanical formulations and biocontrol agents for the management of Fusarium oxysporum f. sp. cubense (Foc) causing Fusarium wilt in banana. Biol Control 2011;57: 175-83.

[32] Goswami RS, Punja ZK. Molecular and biochemical characterization of defense responses in ginseng (Panax quinquefolius) roots challenged with Fusarium equiseti. Physiol Mol Plant Pathol 2008; 72: 10-20.

[33] Goldwasser Y, Hershenhorn J, Plakhine D, Kleifeld Y, Rubin B Biochemical factors involved in vetch resistance to Orobanche aegyptiaca. Physiol Mol Plant Pathol 1999; 54: 87-96.

[34] Vieira Dos Santos C, Letousey P, Delavault P, Thalouarn P. Defense gene expression analysis of Arabidopsis thaliana parasitized by Orobanche ramosa. Phytopathol 2003; 93: 451-7.

[35] El Hadrami I, Ramos T, El Bellaj M, El Idrissi-Tourane A, Macheix JJ. Asinapic derivative as induced defense compound of date palm against Fusarium oxysporum $f$. sp. abledinis, the agent causing Bayoud disease. J Phytopathol 1997; 145: 329-33.

[36] Dihazi A, Jaiti F, Zouine J, El Hassni M, El Hadrami I. Effect of salicylic acid on phenolic compounds related to date palm resistance against Fusarium oxysporum albedinis. Phytopathol Mediterran 2003; 42: 9-16.

[37] El Hassni M, Jaiti F, Dihazi A, Ait Barka E, Daayf F, El Hadrami I. Enhancement of defense responses against Bayoud disease by treatment of date palm seedlings with an hypoaggressive Fusarium oxysporum isolate. J Phytopathol 2004; 152 (3): 182-9.

[38] Jaiti F, Kassami M, Meddich A, El Hadrami I. Effect of arbuscular mycorrhization on the accumulation of hydroxycinnamic acid derivatives in date palm seedlings challenged with Fusarium oxysporum $f$. sp. albedinis. J Phytopathol 2008; 156 (11-12): 641-6.

[39] Meddich A. Rôle des endomycorhizes VA des zones arides dans la tolérance du trefle et de l'orge austress hydrique. Thèse de Doctorat, Université Cadi Ayyad, Faculté des Sciences Semlalia, Marrakech 2001; p. 234

[40] Phillips JM, Hayman DS. Improved procedures for clearing roots and staining parasitic and vesicular-arbuscular mycorrhizal fungi 
for rapid assessment of infection. Trans Br Mycol Soc 1970; 55: $158-61$.

[41] Strullu DG. Micropropagation of chesnut and conditions of mycorrhizal synthesis in vitro. New Phytol 1986; 102: 95-101.

[42] Plenchette C, Furlan V, Fortin JA. Effects of different endomycorrhizal fungi on five host plant grown on calcined montmorillonite clay. J Am Soc Hortic Sci 1982; 107: 535-8.

[43] Trouvelot A, Kough JL, Gianinazzi-Pearson V. Mesure du taux de mycorhization VA d'un système radiculaire.Recherche de méthodes d'estimation ayant une signification fonctionnelle. In: Gianinazzi S, Ed. Les mycorhizes: physiologie et génétique, 1er séminaire european sur les mycorhizes, Dijon, INRA, Paris 1986; pp. 217-21.

[44] El Idrissi-Tourane A. Importance des polyamines libres et conjuguées et des inhibiteurs de leur biosynthèse dans les mécanismes de défense du palmier dattier (Phoenix dactylifera $\mathrm{L}$ ) vis-à-vis du Fusarium oxysporum $f$. sp. albedinis, agent causal du Bayoud. Thèse de troisième cycle, Faculté des Sciences Semlalia, Université Cadi Ayyad, Marrakech 1995.

[45] Statsoft INC. STATISTICA (data analysis software system), version 6. Tulsa, USA 2001.

[46] Duncan DB. Multiple range and multiple F tests. Biometrics 1955; 11(1): 142 .

[47] Ouahmane L, Thioulouse J, Hafidi M, et al. Soil functional diversity and P solubilization from rock phosphate after inoculation with native or allochtonous arbuscular mycorrhizal fungi. Forest Ecol Manage 2007; 241 (1-3): 200-8.

[48] Wu QS, Xia RX. Arbuscular mycorrhizal fungi influence growth, osmotic adjustment and photosynthesis of citrus under wellwatered and water stress conditions. J Plant Physiol 2006; 163 (4): 417-25.

[49] Fan Y, Luan Y, An L,Yu K. Arbuscular mycorrhizae formed by Penicillium pinophilum improve the growth, nutrient uptake and photosynthesis of strawberry with two inoculum-types. Biotechnol Lett 2008; 30 (8): 1489-94.

[50] Liu J, Wu L, Wei S, et al. Effects of arbuscular mycorrhizal fungi on the growth, nutrient uptake and glycyrrhizin production of licorice (Glycyrrhiza uralensis Fisch). Plant Growth Regul 2007; 52(1): 29-39.

[51] Avio L, Peiiegrino E, Bonari E, Giovannetti M. Natural biofertilizers for organic agriculture: productivity and nutrient uptake of Medicago sativa inoculated with different arbuscular mycorrhizal fungi. $16^{\text {th }}$ IFOAM Organic World Congress, Modena, Italy 2008 .

[52] Joner EJ, Van Aarle IM,Vosatka M. Phosphatase activity of extraradical arbuscular mycorrhizal hyphae: a review. Plant Soil 2000; 226(2): 199-210.

[53] Panina Y, Fravel DR, Baker CJ, Shcherbakova LA. Biocontrol and plant pathogenic Fusarium oxysporum-Induced changes in phenolic compounds in tomato leaves and roots. J Phytopathol 2007; 155: 475-81.

[54] Ozgonen H, Yardimci N, Culal Kilic H. Induction of phenolic compounds and pathogenesis-related proteins by mycorrhizal fungal inoculations against Phytophthora capsici leonian in pepper. Pak J Biol Sci 2009; 12: 1181-7.

[55] Lattanzio V, Lattanzio VMT, Cardinali A. Role of phenolics in the resistance mechanisms of plants against fungal pathogens and insects; In: Phytochemistry: Advances in Research, Filippo Imperato, Ed. 2006; pp. 23-67.

[56] Yedidia I, Shoresh M, Kerem Z, Benhamou N, Kapulnik Y, Chet I. Concomitant induction of systemic resistance to Pseudomonas syringae pv. lachrymans in cucumber by Trichoderma asperellum (T-203) and the accumulation of phytoalexins. Appl Environ Microbiol 2003; 69 (12): 7343-53.

[57] Ashry NA, Mohamed HI. Impact of secondary metabolites and related enzymes in flax resistance and or susceptibility to powdery mildew. World J Agric Sci 2011; 7: 78-85.

(C) Abohatem et al.; Licensee Bentham Open.

This is an open access article licensed under the terms of the Creative Commons Attribution Non-Commercial License (http://creativecommons.org/licenses/by$\mathrm{nc} / 3.0 /$ ), which permits unrestricted, non-commercial use, distribution and reproduction in any medium, provided the work is properly cited. 